\title{
Features and Benefits of the Concession Mechanism in the Sphere of Subsoil Management
}

\author{
Alexander Myaskov ${ }^{1, *}$, Zinaida Nazarova $^{2}$, Yuliya Leonidova ${ }^{2}$, and Daria Shchedrova $^{2}$ \\ ${ }^{1}$ National University of Science and Technology MISiS, College of Mining, 119049, 4 Leninsky av., \\ Moscow, Russian Federation \\ ${ }^{2}$ Sergo Ordzhonikidze Russian State University for Geological Prospecting (Sergo Ordzhonikidze \\ University), 117997, 23 Miklouho-Maclay St., Moscow, Russian Federation
}

\begin{abstract}
The article presents the interaction scheme worked out by the authors which shows state and private sector interests in public-private partnership. Four main possible ways of transferring mineral deposits to an investor for the development are highlighted and tax regulations are described. The authors considered the advantages of the concession as a way to facilitate investment processes in the development of mineral deposits that are difficult to access. The authors compared the risks that occur under concession agreements and production sharing agreements when developing mineral deposits. Data on the historical experience of this form of subsoil management in the world and in Russia are described in the article. The need to elaborate legal platform for application of concession mechanisms in mineral deposits development in Russia has been determined.
\end{abstract}

\section{Introduction}

The experience of recent years shows that private investors do not strive to the regions of Russia that have a unique resource, raw material, energy potential - Eastern Siberia and the Far East. The most important wealth of these regions is numerous deposits of various minerals [6]: the South Yakut, Lensk, Zyryansky and Tunguska coal basins, the Bureinsky coal basin (the Urals, Urgal-Soloni deposits), the Marekanskoe, Khurmulinsky and Liansky brown coal deposits, polymetallic deposits - Verkhne-Mankechenskoe, Zarnitsa, Kutinskoe, Sardana and the silver-polymetallic deposit Prognoz, Kholodninskoe deposit of lead-zinc ores and others. This is due primarily to the fact that the projects for the development of minerals in these poorly developed regions are characterized by complexity, high investment capacity, high risks due to the low degree of exploration of the territories, a great distance from the markets, the lack of necessary production, social and transport infrastructures, investments in the creation of which are often equal to the costs of developing the deposits themselves, complex natural and climatic conditions [1].

*Corresponding author: floranimal@,rambler.ru 
One of the tools for the state regulation of entrepreneurial activities, a promising mechanism for improving the state (public) property management, which includes subsoil resources, can be a concession mechanism of public-private partnership (PPP).

The analysis of scientific literature on the problems of PPP [2-5] allows us to conclude that at the present stage of the Russian economy development, public-private partnership represents the most promising direction in the development of the system of partnership relations between public authorities and private business representatives, including the mineral and raw materials complex. It is implemented on the basis of a harmonious combination of the advantages of the mechanism of state and market regulation of the economic relations system. However, not only the support for the development of private business is a priority task of this type of economic relations, the basis of their development should be the provision of total public interests.

\section{Methods}

Improving the mechanisms of public-private partnerships is actualized by crisis phenomena in modern Russian economy. The state acts as a stabilizing factor within the framework of the proposed model of economic relations, being the organizer, regulator and customer of priority projects of territorial development.

Organizational problems of effective management of state property with private investment are constantly at the intersection of theory and practice of public administration and require regular improvement of the conceptual framework of partner relations between state authorities and business.

Each of the participants in the form of public-private partnerships has certain skills and advantages in implementing investment projects.

As follows from the current legislation and the world practice of mineral deposits development (MDD), there are 4 main ways to transfer MDD to investors for the purpose of their development: license agreement, concession, service contract and production sharing agreement (PSA).

In our opinion, the concession is the most undervalued way of transferring hard-to-reach deposits to investors for development, ensuring the successful implementation of projects for the development of MDD, taking into account the interests of the state, subsoil users and society as a whole. The social significance lies in the solution of social and economic problems, and society as a result wins as a consumer of higher-quality goods and services $[6,11]$.

\section{Results and Discussion}

The concession is not a new form of management, the first concession for the development of minerals was organized in Spain in 1256.

In 1901, in Persia, the first concession for oil production for geological prospecting purposes was carried out. The essence of the concession agreement was that the state transferred the concessionaire the right to use subsoil for a certain fee (royalties - a fixed part of the rent in the form of a specified share of revenues from the sale of manufactured products) on the basis of the risk of geological exploration. The net profit of the concessionaire was the rest of the revenues.

Such a concession model is considered to be traditional and involves granting the concessionaire broad rights for a fee.

In the USSR, during the NEP years, it was also widely practiced to provide subsoil for the development of MDD to foreign legal entities and individuals on concession terms. The 
concessions were widely used in the 20-ies of the last century in the Far East of Russia [8]. This was explained, first of all, by the interest of foreign capital in developing the natural resources of the region. At that time, many American and English entrepreneurs were given the right to develop ore and gold deposits on the basis of a concession agreement. At the same time, the Russian mines used advanced foreign technology and technology: German excavators, English dredges, and light narrow-gage railroads.

The first successful experience of gold mining in Russia was obtained by the VerkhneAmur company with the help of a dredge built in Birmingham under the project of Dutch engineers [9].

Today, the concession abroad is the most common form of public-private partnership in the implementation of large, capital-intensive projects.

Concession mechanisms in the field of subsoil use are used in many countries of the world: USA, France, Great Britain, Kazakhstan, Argentina, Egypt, Mexico, UAE, Norway, Netherlands, Sweden, Italy, etc.

Russian organizations are also engaged in the development of MDD abroad on the basis of concession mechanisms, for example, Gazprom Group companies carry out works in the field of hydrocarbon exploration and production in Libya and Hungary; in December 2016 Rosneft company signed an agreement for buying a stake in the concession agreement from the Italian company Eni for the development of the Zohr gas field in Egypt.

The concession mechanism has a number of advantages over the other ways of transferring the MDD for development:

- $\quad$ a concession contract is a special form of temporary provision of the right for using the property of public legal authority to an individual on a reimbursable basis;

- the concession is a long-term partnership that allows the parties to carry out strategic planning of their activities [10], thus concession agreements have a long (sometimes up to 60-75 years [11]) period, which does not require a permanent prolongation for a period sufficient to complete economically expedient extraction of raw materials;

- $\quad$ the state plays an active-passive role when concluding a concession agreement, it is interested not only in obtaining fiscal benefits and royalties, but also in the efficiency of using its own property, the right for temporary use is transferred to the concessionaire;

- $\quad$ zero budget participation is possible (the public partner does not invest in project financing, the investor realizes the return of investment funds from the project activity revenues);

- $\quad$ the public party does not use budget funds, but uses other forms of support (for example, state guarantees, grants, tax incentives for the investor in this project, allocation of land, guarantee of loading of the facility, etc.);

- the concession fee may be established either in the form of fixed payments to the budget, transferring the property owned by the concessionaire (private partner) to the concessor (public partner) for the ownership and in the form of an established share of the output or income received by the concessionaire as a result of the activities provided by the concession agreement (Table 1);

- in the English-speaking countries concessions are often called agreements "taxroyalty", i.e. agreements "with payment of taxes", which emphasizes their main difference from agreements about product sharing, which actually replaces the collection of taxes [4] (Table 2);

- $\quad$ one of the main advantages of concession agreements is the mechanism for reducing and diversifying the risks of the state (Table 3 ). 
Table 1. Payments in various methods of MDD transfer to the investor for the development.

\begin{tabular}{|c|c|c|}
\hline Licensing & Concession & $\begin{array}{ll}\text { The Production } & \text { Sharing } \\
\text { Agreement (PSA) } & \\
\end{array}$ \\
\hline $\begin{array}{l}\text { payment for the right to use } \\
\text { subsoil (a discount may be } \\
\text { made for payments for the } \\
\text { right to use subsoil, taking } \\
\text { into account the depletion of } \\
\text { subsoil) }\end{array}$ & \multirow{5}{*}{$\begin{array}{l}\text { payment made by the } \\
\text { concessionaire to the grantor } \\
\text { in the period of use } \\
\text { (operation) of the concession } \\
\text { agreement object. } \\
\text { The concession fee can be set } \\
\text { in the form of: } \\
\text { 1) fixed payments made } \\
\text { periodically or at a time to } \\
\text { the budget of the appropriate } \\
\text { level; } \\
\text { 2) established share of } \\
\text { products or incomes received } \\
\text { by the concessionaire as a } \\
\text { result of the activities } \\
\text { specified in the concession } \\
\text { agreement; } \\
\text { 3) transferring to the grantor } \\
\text { the ownership for the } \\
\text { property owned by the } \\
\text { concessionaire. }\end{array}$} & $\begin{array}{l}\text { one-off payments for the use } \\
\text { of subsoil in the event } \\
\text { defined in the agreement and } \\
\text { license (bonuses) }\end{array}$ \\
\hline $\begin{array}{llr}\text { payments } & \text { for } & \text { the } \\
\text { reproduction } & \text { of } & \text { mineral } \\
\text { resources } & & \end{array}$ & & $\begin{array}{l}\text { annual payments for } \\
\text { contractual water area and } \\
\text { seabed areas }\end{array}$ \\
\hline $\begin{array}{l}\text { charge for the use of the } \\
\text { water area and seabed areas }\end{array}$ & & $\begin{array}{l}\text { fee for participation in the } \\
\text { tender (auction), fee for } \\
\text { issuing a license }\end{array}$ \\
\hline \multirow{2}{*}{$\begin{array}{l}\text { fees for the licenses for the } \\
\text { right to use subsoil }\end{array}$} & & $\begin{array}{l}\text { regular payments for the use } \\
\text { of subsoil (rentals) }\end{array}$ \\
\hline & & $\begin{array}{l}\text { compensation of state } \\
\text { expenses for prospecting and } \\
\text { exploration of minerals }\end{array}$ \\
\hline \multirow{2}{*}{$\begin{array}{l}\text { taxes, excises and other } \\
\text { charges and payments } \\
\text { provided for by the } \\
\text { legislation of the Russian } \\
\text { Federation, including } \\
\text { payment for the land plots } \\
\text { used by them }\end{array}$} & \multirow{2}{*}{$\begin{array}{l}\text { taxes, excise and other } \\
\text { charges and payments } \\
\text { provided by the legislation of } \\
\text { the Russian Federation. } \\
\text { The property transferred to } \\
\text { the concessionaire and (or) } \\
\text { created by it in accordance } \\
\text { with the concession } \\
\text { agreement is a subject to } \\
\text { taxation from the } \\
\text { concessionaire; agreement } \\
\text { concession the } \\
\text { operations, the duties of the } \\
\text { VAT payer are also given to } \\
\text { the concessionaire }\end{array}$} & $\begin{array}{l}\text { compensation for damage } \\
\text { caused as a result of the } \\
\text { implementation of work } \\
\text { under the agreement to } \\
\text { indigenous small-numbered } \\
\text { peoples of the Russian } \\
\text { Federation in places of their } \\
\text { traditional residence and } \\
\text { economic activities }\end{array}$ \\
\hline & & $\begin{array}{l}\text { taxes, excises and other } \\
\text { charges and payments } \\
\text { provided by the legislation of } \\
\text { the Russian Federation (when } \\
\text { implementing the agreement, } \\
\text { a special procedure for } \\
\text { calculating and paying taxes } \\
\text { and fees is applied) }\end{array}$ \\
\hline
\end{tabular}

Table 2. Tax payments for various methods of MDD transfer to the investor for the development.

\begin{tabular}{|l|l|l|l|l|}
\hline Taxes & $\begin{array}{l}\text { Licen } \\
\text { sing }\end{array}$ & $\begin{array}{l}\text { Concessio } \\
\text { ns }\end{array}$ & PSA & Contracts \\
\hline Corporate income tax & + & + & + & + \\
\hline Value added tax & + & + & + subject to reimbursement & + \\
\hline Mineral extraction tax & + & + & + & + \\
\hline Corporate property & + & + & - & + \\
\hline
\end{tabular}




\begin{tabular}{|l|l|l|l|l|}
\hline tax & & & & \\
\hline Land tax & + & + & + subject to reimbursement & + \\
\hline Water tax & + & + & + subject to reimbursement & + \\
\hline $\begin{array}{l}\text { Payments for the use } \\
\text { of natural resources }\end{array}$ & + & + & + subject to reimbursement & + \\
\hline $\begin{array}{l}\text { Payment for negative } \\
\text { impact on the } \\
\text { environment }\end{array}$ & + & + & + subject to reimbursement & + \\
\hline Government duty & + & + & + subject to reimbursement & + \\
\hline Customs duties & + & + & $\begin{array}{l}\text { + subject to reimbursement, } \\
\text { exemption from customs duties }\end{array}$ & + \\
\hline Excise tax & + & + & + subject to reimbursement & + \\
\hline Transport tax & + & + & - & + \\
\hline Regional taxes & + & + & - & + \\
\hline Local taxes & + & + & - & + \\
\hline
\end{tabular}

Table 3. Risks under concession agreements and production sharing agreements.

\begin{tabular}{|c|c|c|}
\hline Types of risks & Concessions & PSA \\
\hline $\begin{array}{l}\text { political } \\
\text { (country) }\end{array}$ & partially transferred to the state partner & $\begin{array}{l}\text { completely transferred to the } \\
\text { state partner }\end{array}$ \\
\hline $\begin{array}{l}\text { technical and } \\
\text { technological } \\
\text { (production, } \\
\text { mining and } \\
\text { geological) }\end{array}$ & $\begin{array}{l}\text { completely fall on the private partner: the } \\
\text { risks of construction, operation, planning, } \\
\text { achievement of results, risk of } \\
\text { obsolescence }\end{array}$ & $\begin{array}{l}\text { the risk of exploratory work } \\
\text { falls entirely on the investor (in } \\
\text { case of impossibility of } \\
\text { exercising at the expense of } \\
\text { budgetary funds, in other cases } \\
\text { - the risk is minimal) }\end{array}$ \\
\hline $\begin{array}{l}\text { economic } \\
\text { (financial) }\end{array}$ & $\begin{array}{l}\text { - the economic risk is borne by the state } \\
\text { partner, the private partner; } \\
\text { the financial risk is borne by the } \\
\text { participants of the PPP project depending } \\
\text { on the origin of this risk; } \\
\text { - currency risk is borne by the state } \\
\text { partner (or minimized for him - if the } \\
\text { income is in the commodity form) }\end{array}$ & $\begin{array}{l}\text { - fall on the investor } \\
\text { - the currency risk of the state } \\
\text { partner is minimized (income } \\
\text { in commodity form) }\end{array}$ \\
\hline managerial & completely fall on a private partner & completely fall on the investor \\
\hline legal & transferred to the state partner & $\begin{array}{l}\text { - transferred to the state } \\
\text { partner } \\
\text { - the private partner must take } \\
\text { into account the risk of } \\
\text { changing legislation }\end{array}$ \\
\hline environmental & completely fall on a private partner & $\begin{array}{l}\text { - fall on the investor } \\
\text { - present at all stages of the } \\
\text { project life cycle }\end{array}$ \\
\hline force majeure & completely fall on a private partner & fall on the investor \\
\hline
\end{tabular}

\section{Conclusion}

There are risks associated exceptionally with the specifics of concession agreements (risks of non-completion of construction, increase in cash rates for attracted funds). In the case of projects implemented based on production sharing agreements, it is necessary to specifically identify the risk factors that arise when various tasks are being solved: the risk of hazardous phenomena, the risk of negative development scenarios, and the risk of unstable operating conditions or decision-making under uncertainty. 
However, under the existing legislation in the Russian Federation, subsoil resources cannot be subject to a concession agreement. The issue of the use of concessionary mechanisms with the assistance of investment processes in the development of hard-toreach MDD is topical; it requires further research and amending the current legislation.

Concession agreements can also become one of the alternative sources of financing the development of transport infrastructure. It will significantly help private companies to participate in the development of hard-to-reach mineral deposits.

The creation of infrastructure opens up great opportunities for poorly developed regions. An example is Tuva. Significant deposits of coking and steam coal, cobalt, gold, non-ferrous and rare metals, as well as various building materials have been discovered on the territory of the republic, the actual volume of production of which is low due to the inability to export large amounts of cargo from the republic. The emergence of transport infrastructure will increase the volume of mining and give a powerful impetus to the economic development of this region.

Thus, concessions are not only a qualitative way of attracting investment resources to the economy of the country, but also serves as an effective tool for the development of both the regional economy and the mineral and raw materials complex.

\section{References}

1. Russian Federation Federal Law “On concession agreements" 115-FL (Law Office, Moscow, 2015)

2. V. I. Efimov, Formation of economic and legal instruments of public-private partnership for innovative development of Kuzbass enterprises in the conditions of crisis (Nedra, Tula, 2015)

3. M. K. Klubnichkin, Mineral Resourcrs of Russia, 6, 22 (1994)

4. S. Kudiyarov, Expert, 50, 26 (2017)

5. V .I. Lisov, Increase of efficiency of activity of geological prospecting and mining enterprises in modern conditions, (Geosystems Research Institute, Moscow, 2014)

6. Z. M. Nazarova, Yu. A. Leonidova., Proceedings of Higher Schools, Geology and Exploration, 2, 82 (2017)

7. Nemchaninova M.A., Public-private partnership, 2:2, 87 (2015)

8. N. G. Privalov, A. G. Leonovich, Applied Economy, 2:46, 71 (2013).

9. R. Admiraal, A. R. Sequeira, M. P. McHenry, D. Doepel, The Extractive Industries and Society, 4:2, 240 (2017)

10. K. Y. Hoon, Y. Y. Chih, C. W. Ibbs, California management review, 51:2, 51 (2009)

11. M. E. Gross, Aligning Public-Private Partnership Contracts with Public Objectives for Transportation Infrastructure (Blackburg, Virginia, 2010) 